\title{
HIROSHIMA UNIVERSITY RADIOCARBON DATES II WEST AND SOUTH COASTS OF SRI LANKA
}

\author{
JINADASA KATUPOTHA* \\ Department of Geography, Hiroshima University, \\ 1-1-89, Higashi Senda Machi, Naka-ku, \\ Hiroshima 730, Japan \\ INTRODUCTION
}

Geologic samples for ${ }^{14} \mathrm{C}$ age measurements were collected from the west, southwest and south coasts of Sri Lanka during October and November 1986. Sample points were leveled based on the Colombo datum level. Results presented below were obtained by liquid scintillation counting of methanol for coral and shell samples. Ages were measured from December 1986 to May 1987, at the Department of Geography, Hiroshima University, Radiocarbon Dating Laboratory, using the laboratory procedure described by Fujiwara and Nakata (1984). Sample preparation techniques were similar to those mentioned in the first list (Katupotha, 1988). The results are expressed in radiocarbon years relative to AD 1950 based on the Libby halflife of $5568 \pm 30$ years, using the new oxalic acid standard (SRM 4900C) as 'modern' (Stuiver, 1983).

The tidal range on Sri Lanka coasts is small, ranging from the mean low water spring (MLWS) at $-37 \mathrm{~cm}$ to mean high water spring (MHWS) at $+40 \mathrm{~cm}$ from the mean sea level (MSL) (data based on the standard point of Colombo, datum level $38 \mathrm{~cm}$ below MSL. Tide tables, vol 2, Pacific and Indian Oceans, 1982). However, high waves (height $5 \mathrm{~m}$ or more) are seen along the southwest and south coasts and are related to the strong southwest monsoon season from May to September. The present living corals thrive from MLWS to $8 \mathrm{~m}$ and $4 \mathrm{~m}$ in depth in fringing reef and lagoon reef areas at Hikkaduwa, respectively (Mergner \& Scheer, 1974).

\section{ACKNOWLEDGMENTS}

This data collection forms part of the author's doctorate program at the Department of Geography, Hiroshima University, sponsored by the Ministry of Education, Science and Culture, Japan. I am indebted to my supervisor, Kenzo Fujiwara for his guidance and useful advice, and to Takashi Nakata, who helped me with the laboratory procedures. Grateful thanks are due Marcus Karunanayake, Department of Geography, University of Sri Jayewardenepura, for assistance and encouragement during field work. I wish to thank N P Wijayananda, National Aquatic Resources Agency (NARA), Sri Lanka, who helped me collect several samples, and H W S Karunaratne (Surveyor, NARA, Survey Department of Sri Lanka) who helped me measure the sample sites. I also thank David Hopley, James Cook University, Australia, and Helmut Brückner, University of Duessel-

*Present address: Department of Geography, University of Sri Jayewardenepura, Gangodawila, Nugegoda, Sri Lanka 
dorf, Germany for reviewing the manuscript. Thanks are also due Joe Hicks, Hiroshima University, for his help on this manuscript.

\section{GEOLOGIC SAMPLES}

\section{West Coast series}

HR-235. Chilaw

$1680 \pm 60$

Shell (Corbidae) from a dug well, SE of Chilaw Town, Chilaw dist $\left(7^{\circ} 33^{\prime}\right.$ $40^{\prime \prime} \mathrm{N}, 79^{\circ} 48^{\prime} 05^{\prime \prime} \mathrm{E}$ ), depth $1.5 \mathrm{~m}$ approx below msl. Comment: shell belonging to brackish form living in inter-tidal zone was covered from base to top by fine sand (wind blown), coarse sand with pebbles (terrestrial ?) ca $4.5 \mathrm{~m}$ thick since Late Holocene (Early Subatlantic/Early Subboreal).

\section{HR-271. Fort-Colombo}

$$
5790 \pm 80
$$

Peat sample from pit at Fort in Colombo, Colombo dist, near Beira Lake $\left(6^{\circ} 55^{\prime} 00^{\prime \prime} \mathrm{N}, 79^{\circ} 50^{\prime} 40^{\prime \prime} \mathrm{E}\right)$, depth ca $30 \mathrm{~cm}$ below msl. Comment: fibrous dark-brown to black peat with soft dark-gray organic silty clay in part shows that brackish marsh developed in the area following Holocene transgression. Age, mid-Holocene (Main Atlantic), and level are similar to first age group on SW and S coast series (see General Comment).

\section{Southwest Coast series}

Samples from well-developed buried coral reef patches and emerged reef patches, Galle dist. Dates correlated with mid-Holocene (Main Atlantic) and Late Holocene (Late Subboreal). Upright branching (Acropora) and massive (Porites) corals of buried reef patches (coral quarries nos. 1 and 2) show that accumulation of materials was not caused by catastrophic events such as storm wave action. Dated corals from emerged reef patches also were in growth position.

HR-236. Dimbulduwa (Akurala)

Coral (Acropora) from coral quarry no. $1\left(6^{\circ} 12^{\prime} 10^{\prime \prime} \mathrm{N}, 80^{\circ} 03^{\prime} 00^{\prime \prime} \mathrm{E}\right)$, depth $1.7 \mathrm{~m}$ below msl.

HR-237. Dimbulduwa (Akurala)

Coral (Acropora) from coral quarry no. 1, at same loc as HR-236, depth $3.4 \mathrm{~m}$ below msl.

HR-238. Akurala

Coral (Acropora) from emerged reef patch $\left(6^{\circ} 10^{\prime} 30^{\prime \prime} \mathrm{N}, 80^{\circ} 03^{\prime} 30^{\prime \prime} \mathrm{E}\right)$, elev $50 \mathrm{~cm}$ above $\mathrm{msl}$.

HR-239. Akurala

$6170 \pm 70$

Coral (Platygyra) from emerged reef patch (ca $75 \mathrm{~m} \mathrm{~N}$ of HR-238), elev $10 \mathrm{~cm}$ above msl.

HR-240. Akurala (Telwatte)

$5840 \pm 80$

Coral (Acropora) from emerged reef patch $\left(6^{\circ} 10^{\prime} 10^{\prime \prime} \mathrm{N}, 80^{\circ} 03^{\prime} 50^{\prime \prime} \mathrm{E}\right)$, cemented with beach rock, elev $60 \mathrm{~cm}$ above msl. 
HR-241. Akurala (Telwatte)

$5980 \pm 70$

Coral (Montipora) from emerged reef patch, near and S of HR-240, cemented with beach rock, elev $60 \mathrm{~cm}$ above msl.

HR-242. Hikkaduwa

$3210 \pm 70$

Coral (Goniastrea) from emerged reef patch $\left(6^{\circ} 07^{\prime} 45^{\prime \prime} \mathrm{N}, 80^{\circ} 05^{\prime} 45^{\prime \prime}\right.$ E), N of HR-116 as mentioned previously (Katupotha, 1988), cemented with beach rock, elev $1.0 \mathrm{~m}$ above msl.

HR-243. Hikkaduwa

$2560 \pm 60$

Coral (Goniastrea) from emerged reef patch, near and E of HR-116, cemented with beach rock, elev $1.0 \mathrm{~m}$ above msl.

HR-244. Dadalla

$5200 \pm 70$

Coral (Platygyra) from emerged reef patch $\left(6^{\circ} 02^{\prime} 25^{\prime \prime} \mathrm{N}, 80^{\circ} 11^{\prime} 35^{\prime \prime}\right.$ E), cemented with beach rock, elev $20 \mathrm{~cm}$ above msl.

HR-245. Dadalla

$5480 \pm 70$

Coral (Goniopora) from emerged reef patch, near and E of HR-244, cemented with beach rock, elev $10 \mathrm{~cm}$ above msl.

HR-246. Mihiripenna

$5600 \pm 70$

Coral (Acropora) from coral quarry no. $2\left(6^{\circ} 00^{\prime} 20^{\prime \prime} \mathrm{N}, 80^{\circ} 15^{\prime} 50^{\prime \prime} \mathrm{E}\right)$, depth $70 \mathrm{~cm}$ below msl.

HR-247. Mihiripenna

$5630 \pm 70$

Shell (Tridacnidae) from coral quarry no. 2, at same loc as HR-246, depth $1.2 \mathrm{~m}$ below msl.

HR-248. Mihiripenna

$\mathbf{5 9 7 0} \pm \mathbf{7 0}$

Coral (Porites) from coral quarry no. 2, at same loc as HR-246, depth $1.4 \mathrm{~m}$ below msl.

\section{HR-249. Mihiripenna}

$5910 \pm 70$

Coral (Acropora) from coral quarry no. 2, at same loc as HR-246, depth $2.0 \mathrm{~m}$ below msl.

\section{HR-250. Koggala}

Coral (Goniopora) from emerged reef patch $\left(5^{\circ} 59^{\prime} 00^{\prime \prime} \mathrm{N}, 80^{\circ} 19^{\prime} 25^{\prime \prime}\right.$ E), elev $40 \mathrm{~cm}$ above msl.

General Comment: dated sequences of coral quarries nos. 1 and 2 reveal that corals developed in inland bays or lagoons where factors were well-fitted to growth of coral, and gradually formed reefs in many places on SW coast in mid-Holocene. In comparing levels of present-living corals with lowest and upper levels of dated coral samples of quarry nos. 1 and 2, it is estimated that msl was at least $50 \mathrm{~cm}(10 \mathrm{~cm}+37 \mathrm{~cm} \approx 50 \mathrm{~cm})$ higher at $6170 \pm 80 \mathrm{BP}$ than at present, and at least $1.0 \mathrm{~m}(50 \mathrm{~cm}+37 \mathrm{~cm} \approx 1.0 \mathrm{~m})$ at $5380 \pm 80 \mathrm{BP}$. 
Coral samples from emerged reef patches indicate two separate age groups:

1) from $6170 \pm 70 \mathrm{BP}$ to $5350 \pm 80 \mathrm{BP}$; 2) from $3210 \pm 70 \mathrm{BP}$ to $2560 \pm 60$

BP. These ages also show that sea level was higher than at present during mid-Holocene phases.

\section{South Coast series}

Samples from emerged reef patches, buried coral reefs and shell beds. Dated corals of emerged reef patches and buried coral reef patches were in growth position. Dates correlated with mid-Holocene (Main Atlantic) and late Holocene (Early and Late Subboreal).

HR-251. Aranwala

$2330 \pm 60$

Coral (Goniastrea) from emerged reef patch, Aranwala, Galle dist $\left(5^{\circ}\right.$ $58^{\prime} 00^{\prime} \mathrm{N}, 80^{\circ} 22^{\prime} 30^{\prime \prime} \mathrm{E}$ ), elev $40 \mathrm{~cm}$ above msl.

\section{HR-252. Aranwala}

$5540 \pm 70$

Coral (Goniopora) from emerged reef patch, near and E of HR-251, elev $30 \mathrm{~cm}$ above $\mathrm{msl}$.

HR-253. Aranwala

$2250 \pm 60$

Coral (Goniastrea) from emerged reef patch, near and E of HR-252, elev $10 \mathrm{~cm}$ above $\mathrm{msl}$.

HR-254. Denuwala

$2540 \pm 60$

Coral (Acropora) from emerged reef patch, Denuwala, Matara dist $\left(5^{\circ}\right.$ $57^{\prime} 55^{\prime \prime} \mathrm{N}, 80^{\circ} 23^{\prime} 10^{\prime \prime} \mathrm{E}$ ) elev $70 \mathrm{~cm}$ above $\mathrm{msl}$.

HR-255. Denuwala

$2580 \pm 60$

Coral (Galaxea) from emerged reef patch, near and E of HR-254, elev $50 \mathrm{~cm}$ above $\mathrm{msl}$.

\section{HR-256. Denuwala}

Coral (Acropora) from emerged reef patch, near and E of HR-255, elev $50 \mathrm{~cm}$ above msl.

\section{HR-257. Denuwala}

Coral (Favites) from emerged reef patch, near and E of HR-256, elev $40 \mathrm{~cm}$ above msl.

General Comment: coral dates at Aranwala and Denuwala also indicate that there are two separate age groups, which are quite similar to age groups on Southwest Coast series.

HR-258. Palalla-Weligama

$4420 \pm 70$

Shell (Veneridae) from core coll with hand augur at Weligama, Matara dist $\left(5^{\circ} 59^{\prime} 50^{\prime \prime} \mathrm{N}, 80^{\circ} 25^{\prime} 55^{\prime \prime} \mathrm{E}\right)$, elev from $1.8 \mathrm{~m}$ to $1.9 \mathrm{~m}$ above msl. Comment: sample composed of beach deposits. 
HR-259. Palalla-Weligama

$4560 \pm 60$

Shell (Veneridae) from core coll with hand augur, ca $30 \mathrm{~m}$ to $\mathrm{W}$ of HR258, elev $1.3 \mathrm{~m}$ above msl. Comment: bivalves were embedded in black-togreenish lagoonal mud.

HR-260. Madihe

$4330 \pm 60$

Coral (Acropora) from coral quarry no. 3, Madihe, Matara dist ( $5^{\circ} 56^{\prime}$ $10^{\prime \prime} \mathrm{N}, 80^{\circ} 30^{\prime} 35^{\prime \prime} \mathrm{E}$ ) elev $10 \mathrm{~cm}$ above msl.

HR-261. Madihe

$4850 \pm 70$

Coral (Acropora) from coral quarry no. 3, at same loc as HR-260, depth $1.3 \mathrm{~m}$ below $\mathrm{msl}$.

HR-262. Walgama (Madihe)

$4720 \pm 60$

Coral (Acropora) from coral quarry no. 4 , Walgama, Matara dist $\left(5^{\circ} 56^{\prime}\right.$ $25^{\prime \prime} \mathrm{N}, 80^{\circ} 30^{\prime} 45^{\prime \prime} \mathrm{E}$ ), depth from $10 \mathrm{~cm}$ to $30 \mathrm{~cm}$ below $\mathrm{msl}$.

HR-263. Walgama (Madihe)

$4830 \pm 70$

Coral (Acropora) from coral quarry no. 4, at same loc as HR-262, depth $2.3 \mathrm{~m}$ below msl.

General Comment: regarding stratigraphic and deposition pattern of exposed quarries at Madihe and Walgama, upright branching Acropora and plate type were in growth position. HR-262 and -263 subm by N P Wijayananda.

HR-269. Pallikkudawa

$5610 \pm 70$

Coral (Goniastrea) from emerged reef patch, Hambantota dist $\left(6^{\circ} 01^{\prime}\right.$ $00^{\prime \prime} \mathrm{N}, 80^{\circ} 17^{\prime} 30^{\prime \prime} \mathrm{E}$ ), elev $40 \mathrm{~cm}$ above msl.

HR-270. Pallikkudawa

$5470 \pm 70$

Coral (Platygyra) from emerged reef patch, very near HR-269, elev $60 \mathrm{~cm}$ above msl. Comment: ages and levels at Pallikkudawa coincide with first age group on SW coast.

HR-264. Hatagala (Hungama)

$4440 \pm 60$

Shell (Veneridae) from exposed deposits, Hambantota dist $\left(6^{\circ} 06^{\prime} 35^{\prime \prime}\right.$ $\mathrm{N}, 80^{\circ} 56^{\prime} 50^{\prime \prime} \mathrm{E}$ ), elev $80 \mathrm{~cm}$ above msl. Comment: shells gathered in lagoon floors and were deposited in situ following coastal progradation since Late Subboreal. Sample subm by N P Wijayananda.

\section{HR-265. Kalametiya}

$3570 \pm 60$

Shell (Veneridae) from exposed shell deposit, Hambantota dist $\left(6^{\circ} 05^{\prime}\right.$ $\left.08^{\prime \prime} \mathrm{N}, 80^{\circ} 56^{\prime} 45^{\prime \prime} \mathrm{E}\right)$ elev $1.10 \mathrm{~m}$ above msl. Comment: shell was composed mainly of coarse sand and calcareous clay.

HR-266. Kalametiya

$4460 \pm 60$

Shell (Veneridae) from exposed shell deposit $\left(6^{\circ} 05^{\prime} 15^{\prime \prime} \mathrm{N}, 80^{\circ} 57^{\prime} 08^{\prime \prime}\right.$ E), elev $2.2 \mathrm{~m}$ above msl. Comment: shells were embedded in black-to-blue- 
black mud and clay; it is assumed that HR-265 and -266 gathered (in situ ?) in lagoon floors following coastal progradation since Late Subboreal.

\section{HR-267. Kalametiya}

$3960 \pm 60$

Shell (Veneridae) from exposed shell deposit $\left(6^{\circ} 06^{\prime} 10^{\prime \prime} \mathrm{N}, 80^{\circ} 57^{\prime} 15^{\prime \prime}\right.$ E), elev $2.0 \mathrm{~m}$ above msl. Comment: shells and shell debris were composed of fine-to-coarse sand. Composition of materials shows that they were accumulated at rims of emerged coastal embayments by wave action.

\section{HR-268. Udamalala}

$4650 \pm 70$

Shell (Veneridae) from midden of lake margin, Hambantota dist $\left(6^{\circ} 10^{\prime}\right.$ $15^{\prime \prime} \mathrm{N}, 80^{\circ} 10^{\prime} 00^{\prime \prime} \mathrm{E}$ ), elev ca $5.0 \mathrm{~m}$ above msl. Comment: shell layer consists of uniform species of shell ca $20 \mathrm{~cm}$ thick; presently being covered by reddish brown wind-blown sand. Shells were probably left by early inhabitants during daily activities.

General Comment: dated coral samples from emerged reef patches at Aranwala, Denuwala, and Pallikkudawa are quite similar to age groups on SW coast series. Dated sequences of coral quarries nos. 3 and 4 reveal that growth of corals were continued inland bays or lagoons (to W of Dondra Head) during Late Holocene (Early Subboreal).

Shell and coral debris at Palalla (HR-258) show that materials accumulated on backshore beaches by wave action, but bivalves, which were embedded in black-to-greenish lagoonal mud (HR-259), are probably in situ. Dates of deposits indicate that shell belonging to marine form lived in intertidal zone and were extended ca $4 \mathrm{~km}$ inland from shore in mid-Holocene.

As for deposition pattern and composition of shell deposits in Hambantota dist, shells probably accumulated at rims of emerged coastal embayments or lagoon floors by three processes: 1) bulk of valves piled up by wave action on rims of coastal embayments following coastal progradation since Late Holocene (Late Subboreal); 2) shells gathered in lagoon floors of marine or brackish pools, and they were deposited (in situ ?) since Late Subboreal; 3) shells on coastal hills and dunes left by early inhabitants during daily activities.

These and previous dates (Katupotha, 1988) indicate that sea level was at least $1.0 \mathrm{~m}$ or higher than present msl, from mid-Holocene (Main Atlantic) to Late Holocene (Early Subatlantic), with minor oscillations. It is assumed that local palaeo-sea level was not lower than at present during above-mentioned period.

\section{REFERENCES}

Fujiwara, K and Nakata, T, 1984, Methanol liquid scintillation radiocarbon dating (I): Fac Lit Bull, Hiroshima Univ, v 44, p 120-134 (in Japanese with English abs).

Katupotha, J, 1988, Hiroshima University radiocarbon dates I: West and south coasts of Sri Lanka: Radiocarbon, v 30, no. 1, p 125-128.

Mergner, $\mathrm{H}$ and Scheer, G, 1974, The physiographic zonation and the ecological conditions of some Indian and Ceylon coral reefs: Internatl coral reef symposium, 2nd, Proc, Brisbane, v 2, p 30-42.

Stuiver, M, 1983, International agreements and the use of the new oxalic acid standard, in Stuiver, $M$ and Kra, R S, eds, Internatl ${ }^{14} \mathrm{C}$ conf, 11 th, Proc: Radiocarbon, $v 25$, no. 2 , p 793-795. 